\title{
STUDENTS' UNDERSTANDING OF THE REALIZATION OF NOMINALIZATIONS IN SCIENTIFIC TEXT
}

\author{
Fatonah \\ Politeknik Manufaktur Negeri Bandung \\ email: fatonah.fatonah@yahoo.com
}

\begin{abstract}
The study reports the investigation of students' understanding of the realization of nominalizations in scientific text. Nominalization that dominates the language of science is defined as the formation of nouns which come from other nouns (e.g. verbs and adjectives). A strategic question comes up, inquiring about undergraduate students' level of understanding of nominalizations in scientific text. This study was conducted among 20 Polytechnic students whose study background is engineering. Some numerical data were used, although this study was basically qualitative. The data were not only taken by carrying out an English test, using a scientific reading text, but also by conducting an interview among some of the participants. This test examined their understanding of nominalization, as it is one of the characteristics of scientific text. For analyzing the data, the framework of nominalyzing metaphor was used. This study found that the understanding of nominalizations was at moderate level; that was $65 \%$. It was a bit above the average. It is concluded that this level of understanding nominalizations is not sufficient for the students to comprehend scientific text. Consequently, when reading scientific text, as it was stated in an interview, they experienced some difficulties. This finding is supported by Halliday's statement that scientific language is difficult to read and to understand. It is recommended that for Polytechnic students some grammatical competence be improved by giving an explicit teaching, particularly with the topic of nominalizations. It is hoped that the higher the students' understanding of nominalizations, the higher the students' understanding of scientific text.
\end{abstract}

Keywords: Nominalization, grammatical metaphor, scientific text

\section{STUDENTS' UNDERSTANDING OF THE REALIZATION OF NOMINALIZATIONS IN SCIENTIFIC TEXT}

\begin{abstract}
Abstrak: Penelitian ini melaporkan penelitian tentang pemahaman siswa pada pemakaian nominalisasi dalam teks ilmiah. Nominalisasi, dikatakan mendominasi bahasa ilmiah, didefinisikan sebagai pembentukan kata benda yang berasal dari selain kata benda, misalnya kata kerja dan kata sifat. Suatu pertanyaan mengemuka tentang berapa tingkat pemahaman mahasiswa terhadap pemakaian nominalisasi pada teks ilmiah. Data diambil dari 20 mahasiswa Politeknik yang berlatar-belakang pendidikan keteknikan. Beberapa data diantaranya disajikan dalam bentuk angka, walaupun pada dasarnya studi ini adalah kualitatif. Data diperoleh dengan mengadakan tes yang menguji pemahaman mahasiswa tentang nominalisasi dan dengan wawancara. Data dianalisa dengan menggunakan framework of nominalising metaphor. Temuan dari studi ini ialah bahwa pemahaman siswa terhadap nominalisasi berada pada tingkat menengah, yaitu 65\%, sedikit di atas rata-rata. Studi ini menyimpulkan bahwa bagi mahasiswa Politeknik, tingkatan pemahaman terhadap nominalisasi ini tidak cukup memadai untuk memahami teks ilmiah. Sebagai konsekuensinya, sebagaimana yang dinyatakan saat diwawancara, mereka mengalami kesulitan memahami buku teks yang berbahasa Inggris. Studi ini merekomendasikan bahwa bagi mahasiswa Politeknik kemampuan grammar perlu ditingkatkan dengan explicit teaching, khususnya dengan topik bahasan tentang nominalisasi. Diharapkan, dengan adanya peningkatan pemahaman tentang nominalisasi maka pemahaman terhadap teks ilmiah akan meningkat pula.
\end{abstract}

Katakunci: nominalisasi, grammatical metaphor, teks ilmiah 
All use of language embodies a great deal of metaphor. Written language is associated with the use of grammatical metaphor. Grammatical metaphor that dominates the language of science is nominalization. It is also said that language is so central to the whole of educational process, since no-one could conceive of education without it (Halliday, 1992; Halliday \& Martin, 2005). It can be inferred from these statements that language has very prominent roles in educational process, for constructing meanings realized in text. Therefore, the phenomena of using language in educational process need to be investigated, especially with the students' understanding of the realization of nominalizations in scientific text.

There are some previous studies, which have focused on the phenomena of the significant roles of nominalizations in academic writing among graduate students (Ravelli, 1999; Holtz, 2009; and Yuliana, 2011). The study of the same topic conducted by Baratta (2010) reveals different phenomena. He investigates the realization of nominalization development across an undergraduate academic degree program within the community of 'Language, Literacy and Communication' (LCC), part of Humanities. In his study, he found that nominalizations do not necessarily play a prominent role within the academic writing of this community.

Nevertheless, undergraduate students' understanding of nominalizations has not been studied, especially among the students whose study program is majoring in engineering. That is the reason for the researcher to investigate this phenomenon. In addition, another argument to conduct this study is that students need to comprehend the realization of nominalizations due to its domination in scientific language (Halliday \& Martin, 2005). Despite this, to the researcher knowledge, the topic of nominalizations has not been taught in English program in Polytechnic in Indonesia whose study background is engineering. Thus, to portray this phenomenon, the researcher carries out this investigation in Polytechnic in Bandung, Indonesia.

Based on the above statements, this research is conducted in order to address a research problem, what the students' level of understanding of the realization of nominalizations in scientific text is. To answer the question stated above, the researcher investigates the students' understanding of nominalizations in a scientific text, taken from an engineering textbook (Dieter, 1991).

This study is also intended to contribute to English education theoretically, practically, and professionally. This contribution is particularly essential to the teaching of scientific writing to undergraduate students.

Theoretically, it is expected that the results of this study increase the findings of the investigation of the same topic, and to provide wider literature of nominalizations. Accordingly, they will encourage further investigation on the application of nominalizations in academic written text.

Practically, the finding of this research might develop the educational practice; that is by employing the topic of nominalizations into the English teaching program, especially in the academic writing skill. They will also enable practitioners in education to improve the condition of technical English teaching for Polytechnic students.

Professionally, the report of the study will not only contribute to the professional sources in the teaching profession in Polytechnic in particular, but also in teaching technical English in wider scope. It is also hoped that these results may increase the teachers' awareness of the importance of nominalizations in academic texts. 
The investigation of nominalization in written texts involves a transference from a 'congruent' form of expression to a 'metaphorical', as stated by Veel (cited in Christie \& Martin, 2000, p. 184). Accordingly, the next theoretical review is the brief elaboration on grammatical metaphor before reviewing the main theory of nominalization.

Grammatical metaphor. It is mentioned as one of the characteristics of scientific English. It is also said that grammatical metaphor that dominates the language of science is nominalization (Halliday \& Martin, 2005). Furthermore, they also put forward an opinion that "there is a high level of nominalization in scientific text in which action and events are presented as noun than as verbs" (1998, in Paltridge, 2006, p. 15). Some examples of grammatical metaphors are written below.

1. They prepare a 9-wired cable.

2. The preparation of a 9-wired cable...

In these examples, clause 1 is written using verb prepare. In scientific English, in which an agent (they) is usually removed, grammatical metaphor is needed. In this case, the appropriate kind of grammatical metaphor is nominalization, in which the process of prepare has become preparation in clause 2 (Knapp et al., 2005; Droga et al., 2011; Eggins, 2004; and Hyland et al., 2004).

In addition, Briones et al. (2003) and Cullip (2000) investigate the application of grammatical metaphors in scientific English, based on Halliday's theory. They found that nominalizations are essential resources for constructing scientific discourse and that nominalizations are the most productive form of grammatical metaphor.

Nominalization. It comes from the word nominalise (verb) which means 'to form a noun from a verb or adjective', for example 'truth' from 'true' (Hornby, 2010, p. 1035). Thus, nominalization is defined as the formation of noun which comes from adjective or verb. It is also defined as the process of turning words that are not normally nouns (e.g.: verbs, conjunctions, adjectives, and adverbs) into nouns; for example, employ (verb) $\rightarrow$ employment (noun) (Eggins, 2004; Knapp \& Watkins, 2005; Droga et al., 2011; Gerot \& Wignell, 1998; Christie \& Martin, 2000).

In addition, nominalization is described as a common form of grammatical metaphor which is read on two levels at once, a grammatical meaning and a discourse semantic meaning. Furthermore, it is also mentioned that scientific writing becomes difficult in certain ways. The difficulties lie more with the grammar than with vocabulary. It is then asserted that "difficulties arise when processes are nominalized so that activities are coded as if they were things" (Martin \& Rose, 2007, pp. 106-7).

The formation of nominalization can be simply done by using the present participle form of the verb, such as singing, cutting, or by adding suffixes, like: -ion; -ment; -al in nominalizations like discussion, development, and proposal. In addition, it is argued that "the process of nominalizing can also be taught to students as an editing strategy" (Knapp et al., 2005, p.208). This is in line with an opinion that because nominalization tends to make text dense and abstract, students still need assistance how to 'unpack' it (Derewianka, 1998).

Furthermore, it is said that for detecting grammatical metaphor, derivation is used. However, derivation does not always indicate a metaphorical form, like suffix -er $\&$-or in singer. In addition, it should of course be remembered that many metaphorical examples are found without any derivational suffix whatsoever, for example fast $\rightarrow$ speed (Ravelli, 1999) 
Effects of nominalization. There are some effects of using nominalization in written texts proposed by some linguists. First, the effect of creating abstract technical term in text argued by Droga et al. (2011), for example:

- When the clouds get heavy, these droplets fall to the ground.

- This is called precipitation.

Second, the effect of condensing previous information into a single word that can be used to move the text along (Droga et al., 2011; Eggins, 2004; and Hyland, 2004), for instance:

- When the sun heats up the water, it evaporates into steam.

- Evaporation causes the steam to rise into the air.

Third, the effect of removing time and actors or those responsible for action, evidence or argument that is also called "a timeless and agentless phenomenon" (Knapp et al. 2005, p. 56). In this case, the Process of failing is shifted into failure. The deletion of the agent allows for more objectivity, indicated in the following example:

- Because the President failed to remove the troops, many deaths occurred.

- The failure to remove the troops resulted in many deaths.

There are some previous studies focusing on the realization of nominalizations in written texts among many fields of study. Some of them are Banks (2005), Galve (1998) and Yuliana (2011). Their studies are briefly described respectively in the following parts of this section.

Banks (2005) studies the historical origins of nominalized process in scientific texts, believing that the linguistic development began with Newton in the late $17^{\text {th }}$ century. Grammatical metaphor in the form of nominalized processes is widely recognized as an important feature in scientific writing. Galve (1998) investigated the phenomenon of grammatical metaphor in written text for science and technology, focusing on nominalizations. It is found that grammatical metaphor can provide clear illustration when approaching the language of science.

In line with the above studies, Yuliana (2011) investigated grammatical metaphors in students' writing and their effects on texts' written characteristics. Her study was conducted among nine research articles of three postgraduate students in a state-owned university in Bandung. It was found that there is a high level of nominalization in written texts, and that nominalization is the dominant type of grammatical metaphor realized in those research articles.

\section{METHOD}

This study is qualitative in nature, but in some of its descriptive analysis, quantitative criteria are used (Croker, 2009, in Heigham et al., 2009). The data in the forms of score are found, but their purpose is merely supplementary, not the central ones.

A state-owned Polytechnic in Bandung, running Diploma III and IV programs, majoring in mechanical engineering, was chosen as the institution to conduct this research for two reasons. First, it was practical, because of its ease, as to save time, finance, and effort, as proposed by Patton (1980, cited in Lincoln \& Guba, 1985).

Second, it was accessible. The researcher has the familiarity with the condition of teaching technical English in this Polytechnic, since she has been teaching English in this educational institution for years. Third, the aim of this study is to portray the phenomenon of students' level of understanding of nominalization, since nominalization has not been taught in English classes of this institution due to the time constrain. So, this Polytechnic is regarded the appropriate site for investigating this phenomenon.

In this study, 20 Polytechnic students of year three were chosen as participants for 
several reasons. First, Polytechnic was programmed for undergraduate students. The purpose of the investigation was to explore the level of understanding of nominalization, especially among undergraduate students. Therefore, Polytechnic students were assumed to be the appropriate participants to participate in this investigation. Fortunately, they were willing to take part in this research.

Second, Polytechnic students' study background is engineering. Their participation in this study was based on the assumption that they had experienced with the use of scientific English in their fields of study, among others when learning engineering textbooks and manuals, when composing operational plans before working in their workshop or laboratory, when presenting their scientific topics in front of the class, and when writing technical report after carrying out practical assignments. Thus, it is regarded that nominalization was frequently applied in their academic activities and texts.

Data collection. In this investigation, the data are collected by carrying out a test and conducting an interview. In the test, a scientific reading text, entitled 'Technological Innovation,' was used. The text of about 202 words, containing 22 nominalized words, was taken from a scientific textbook written by Dieter (1991) from Maryland University. This test was used to follow Droga's \& Humphrey's (2011, pp. 110-111) exercises with the topic of nominalization. The focus of the test is mainly on portraying the level of understanding nominalizations as the results of derivation (Ravelli, 1999).

There are three reasons for using Technological Innovation text. First, the familiarity of this topic among Polytechnic students, since their study background is engineering. Second, the domination of nominalizations in scientific language are argued by some linguists (see Halliday \& Martin, 2005).

Third, the difficulty level of the scientific reading text used in the test is regarded as moderate, viewed from many sources. It is said that written language tends to have around four to six (4-6) lexical words per clause (Halliday \& Martin, 2005). On the other hand, the lexical density of the reading text used in the test is 5.5. Therefore, based on these data, the scientific reading text has an appropriate level to be used.

According to Halliday's (1998, in Ravelli et al., 2004) theory, there are four types of nominalization. In this opportunity, only two are tested based on some arguments. Firstly, it is very hard for undergraduate students of non-English department to understand a text containing all types of nominalization. Secondly, even in native's scientific texts, the four types of nominalization are rarely used. It is evidenced by Glendinning (1973) that there are only two types (not four) of nominalization realized in his text.

The following description is about the procedure of carrying out the test. To start with, every participant was asked to read the scientific text given to them. Then, they were instructed to identify, by underlining, the 22 nominalizations found in the text. After that, they were directly assigned to unpack the nominalizations they had underlined on the test paper. For example, taken from the reading text, 'ability' (as a noun), was unpacked into 'able' (as an adjective). The test paper completed with key answer is attached on Appendix 1. The complete list of nominalizations found in the text, as the key answer, is in Table 1.

The key answer on Table 1 is used to get the scores after the participants' works were checked by using the list on the table above. Score one was not only given for identifying every nominalized word correctly, but also for unpacking it correctly. The maximum 
score for every task, was 22 , since there were 22 nominalizations found in the text. Finally, the scores were classified based on the kind of task and arranged in Table 2 below,

Table 1. Key Answer of the Test

\begin{tabular}{|c|c|c|c|c|}
\hline \multicolumn{5}{|c|}{ List of } \\
\hline Nominalization & $\sum$ & Unpacke & ords & $\sum$ \\
\hline $\begin{array}{l}\text { advancement, } \\
\text { invention }(2 \mathrm{x}) \text {, } \\
\text { innovation }(8 \mathrm{x}) \text {, } \\
\text { diffusion, } \\
\text { initiation, } \\
\text { question, } \\
\text { ability, } \\
\text { well-being, } \\
\text { living, } \\
\text { television, } \\
\text { importance, } \\
\text { opportunities, } \\
\text { contribution } \\
\text { indication, }\end{array}$ & 22 & $\begin{array}{l}\text { advance, } \\
\text { invent } \\
\text { innovate } \\
\text { diffuse, } \\
\text { initiate, } \\
\text { quest, } \\
\text { able, } \\
\text { well-be, } \\
\text { live, } \\
\text { televise, } \\
\text { important, } \\
\text { opportune, } \\
\text { contribute, } \\
\text { indicate, }\end{array}$ & $\begin{array}{r}(2 \mathrm{x}), \\
(8 \mathrm{x})\end{array}$ & 22 \\
\hline
\end{tabular}

Table 2. The Results of the Test

\begin{tabular}{cccc}
\hline$\#$ & \multicolumn{2}{c}{ Percentages of Scores of } & Averag \\
Partc & Underlining & Unpacking & \% \\
\cline { 2 - 3 } P\#1 & 45 & 41 & 43 \\
\hline P\#2 & 64 & 59 & 62 \\
\hline P\#3 & 73 & 55 & 64 \\
\hline P\#4 & 82 & 73 & 78 \\
\hline P\#5 & 95 & 95 & 95 \\
\hline P\#6 & 64 & 55 & 60 \\
\hline P\#7 & 86 & 86 & 86 \\
\hline P\#8 & 59 & 59 & 59 \\
\hline P\#9 & 55 & 23 & 39 \\
\hline P\#10 & 73 & 68 & 71 \\
\hline P\#11 & 59 & 45 & 52 \\
\hline P\#12 & 77 & 73 & 75 \\
\hline P\#13 & 59 & 59 & 59 \\
\hline P\#14 & 77 & 68 & 73 \\
\hline P\#15 & 86 & 82 & 84 \\
\hline P\#16 & 77 & 41 & 59 \\
\hline P\#17 & 73 & 45 & 59 \\
\hline P\#18 & 64 & 59 & 62 \\
\hline P\#19 & 64 & 50 & 57 \\
\hline P\#20 & 77 & 73 & 75 \\
\hline N=20 & $\mathbf{7 0}$ & $\mathbf{6 0}$ & $\mathbf{6 5}$ \\
\hline & & &
\end{tabular}

Table 2 contains the collection of data reporting the achievement of 20 participants. The average score of underlining task is 70 , which is higher than the average score of unpacking task, that is 60 . So, the total of the average achievement is 65 .

In addition to the data mentioned above, there were some other data derived from conducting an interview to some selected participants representing the high, medium, and low achievers. The functions of these interview data were to enhance the main data and to elicit some important information which was not obtained by conducting written test only. In this occasion, a semistructured interview was chosen. It contains verbal questionnaires consisting of questions designed to elicit specific answers (Frankel $\&$ Wallen, 1996). These interview data were inserted while discussing the main data resulted from the test.

\section{Data analyses}

The analyses of the data were intended to respond to the research question in this study, that is about the students' level of understanding of nominalization, as the result of derivation, in a scientific text. The framework of analyzing the data is a taxonomy of nominalizing metaphor proposed by Halliday (1998 in Ravelli \& Ellis, 2004; Christie \& Martin, 2000). The taxonomy containing four types of nominalization are completely posted in Table 3 below.

Table 3. Types of Nominalization

\begin{tabular}{lll}
\hline $\begin{array}{c}\text { Types of } \\
\text { Nom. }\end{array}$ & $\begin{array}{l}\text { Semantic Shifts / } \\
\text { Grammatical Shifts }\end{array}$ & Examples \\
\hline $\begin{array}{l}\text { Type I } \\
\text { metaphor }\end{array}$ & $\begin{array}{l}\text { from quality to entity / } \\
\text { from adject. to noun }\end{array}$ & \\
\hline $\begin{array}{l}\text { Type II } \\
\text { metaphor }\end{array}$ & $\begin{array}{l}\text { from process to entity } \\
\text { /from verb to noun }\end{array}$ & drive - driving \\
\hline $\begin{array}{l}\text { Type III } \\
\text { metaphor }\end{array}$ & $\begin{array}{l}\text { from circumstance to } \\
\text { entity / from adv. / } \\
\text { prep. phrases to noun }\end{array}$ & $\begin{array}{l}\text { speed } \\
\text { frost }- \text { the }\end{array}$ \\
\hline $\begin{array}{l}\text { Type IV } \\
\text { metaphor }\end{array}$ & $\begin{array}{l}\text { from relator to entity / } \\
\text { from conjct. to noun }\end{array}$ & so the result \\
\hline
\end{tabular}

In Table 3, there are four types of nominalization: Types I, II, III and IV. In reality, it is mostly found only the 
application of nominalizations Types I and II. Accordingly, the framework of data analyses implemented in this study is the nominalizations of these types. They consist of Type I, that is the grammatical shifting from adjective to noun; and Type II, from verb to noun, for examples: unstable $\rightarrow$ instability and maintain $\rightarrow$ maintenance.

According to Ravelli (1999), derivation is a device used for detecting grammatical metaphor. Thus, in analyzing the data, the accurate nominalizations counted are the ones as the results of derivation. Nominalizations which are inaccurate are consequently excluded from the analyses. Ravelli further mentions that many metaphorical grammars are found without any derivational suffix, like fast $\rightarrow$ speed. However, derivation does not always indicate a metaphorical form, for example-er and -or, in singer.

The procedure of analyzing the data is described in the following steps. First, the students' works of underlining nominalizations were identified, continued with the identification of the unpacking task. Then, the scores were given to the correct answers. The maximum score was 22 for every task. After the scores were classified, they were transformed into percentages. Later, they were categorized into five: very low, low, medium, high and very high categories. The results the of categorization were finally interpreted.

\section{FINDINGS \& DISCUSSION}

This study found that in general students seem moderately understand nominalization. This moderate understanding is a bit above the average, which is 65 . It was supported by three findings. First, the students' ability in identifying (by underlining) nominalizations was higher than in unpacking them (Graph 1). Second, $55 \%$ of the students' ability were categorized low, $15 \%$ medium, and
$30 \%$ high (Table 3). Third, there was a student with the highest score of 96 and the highest consistency in doing the test.

Graph 1 is specially designed to provide more meaningful illustration of Polytechnic students' phenomena in understanding nominalization. It shows the data resulted from the test. The average score of underlining task is 70, which is higher than the average score of unpacking task, that is 60 . So, the total of the average achievement is 65 .

Moreover, Graph 1 clearly represents the general overview of the levels of understanding on nominalizations among 20 Polytechnic students. The blue line indicates the results of identifying or underlining nominalized words and the orange one shows the results of unpacking the ones within the same reading text. This illustration means that their ability in identifying nominalization is always higher than unpacking, and in some cases they are the same.

This situation was supported by some interviewees. They said they often improved their understanding concerning derived words in their academic activities in Polytechnic. Anyway, they did this without being aware whether these words were derivative or not and without having opportunity to learn to unpack them. The following instances were given by some students when they were interviewed: filing, ability, and maintenance. Even, they did not know that those words could be shifted into file, able, and maintain. Based on these realities, it was easy for them to make mistakes when practising or unpacking those nominalizations, particularly in presenting scientific topics.

This finding is associated to the fact that in English program there was lack of opportunity, for the teacher, to explain the forms or types of nominalization as the results of derivation. The short time spent by 
the teacher to discuss grammatical or lexical problems was when giving oral feedback to students in the classroom after their presentation sessions or when correcting their written assignments.

From the analyses of the data resulted from the test, it is assumed that the students tend to make mistakes in understanding nominalizations because of the lack of knowledge of grammatical resources, especially with the topic of nominalization. That is why explicit teaching is needed by the students, so that they have more understanding of the use of nominalizations.

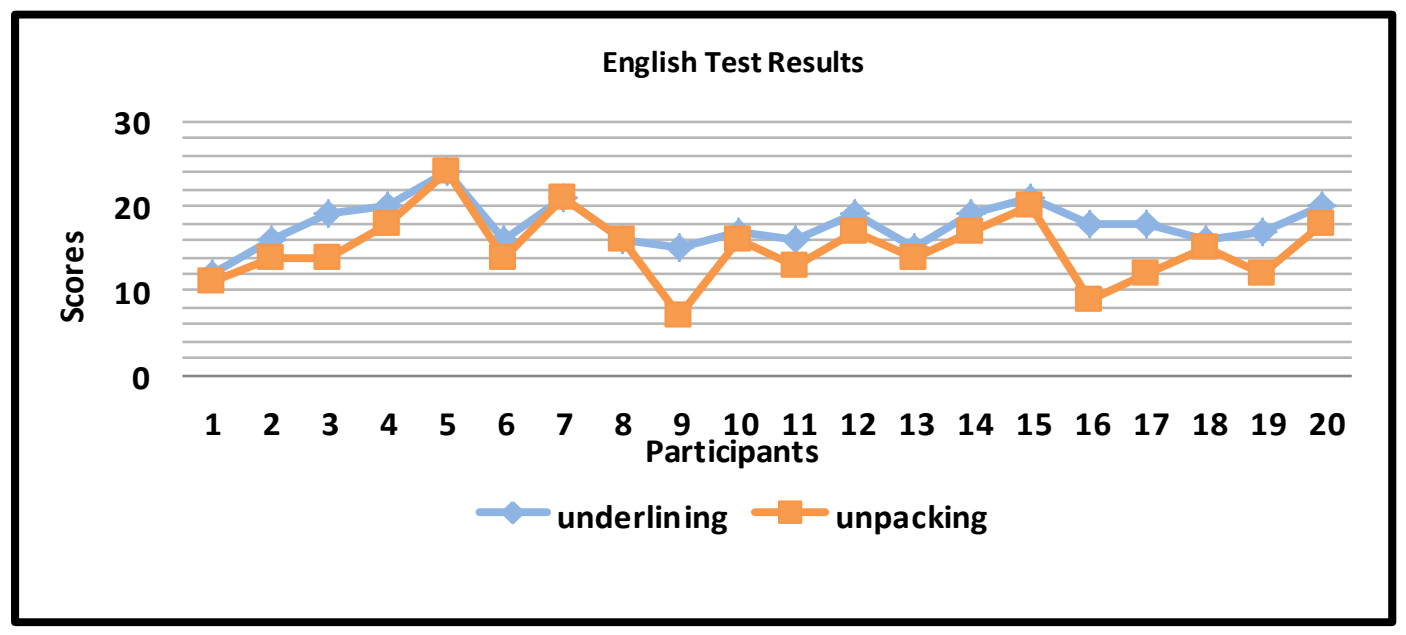

Graph 1: The Results of the Test

\section{Classification of Students' Ability}

For leveling the students' ability in identifying and unpacking nominalization, the test results in Table 1 above are classified into five: very low, low, medium, high and very high. The classification can be seen in Table 4.

Table 4. Students' Levels of Understanding Nominalizations

\begin{tabular}{cccc}
\hline Score Interval & $\mathbf{f}$ & $\boldsymbol{\%}$ & Categories \\
\hline $39-50$ & 2 & 10 & very low \\
\hline $51-62$ & 9 & 45 & Low \\
\hline $63-74$ & 3 & 15 & Medium \\
\hline $75-86$ & 5 & 25 & High \\
\hline $87-98$ & 1 & 5 & very high \\
\hline Total & $\mathbf{n = 2 0}$ & $\mathbf{1 0 0} \%$ & \\
\hline
\end{tabular}

Table 4 shows that there were two students who gained very low scores in the test. They got 43 and 39 respectively. The data indicated that among 22 nominalizations found in the reading text, participant 1 underlined only 10 and unpacked 9 words. So, the total scores gained by P 1 was $43 \%$. The other participant, $\mathrm{P} 9$, is categorized the same, gaining the score of $39 \%$. This participant successfully underlined 15 and unpacked 7 words out of 22 nominalizations.

Table 4 also reported that there were nine participants getting low scores, categorized as low achievers. In average, they underlined 17 and unpacked 13 words. Their scores were in the range of $51-62$. Referring to the same data, there were three participants who have medium category, with the range scores of 63-74. This achievement meant that they underlined 18 words and unpacked 16 out of 22 nominalized words. In the same data, there were also five participants, possessing the scores of 75-86, categorized as the high achievers. In average, they underlined about 20 words and unpacked about 19 words. 
It was also reported that there were 11 students below average scores. They were interpreted to have some difficulties in understanding the application of nominalization in the scientific text. It was openly acknowledged by some low achievers when interviewed, saying that they could not understand engineering textbook, like 'trigonometry', if it was not explained explicitly. Consequently, they were often demotivated to read the textbooks written in scientific language. Furthermore, their background of learning experience did support their achievement as argued that in their high school they did not take any English course because of no motivation to do it, and even they did not like it.

Based on the students' achievements in Test 1 , there was one participant who got the highest score. It was 9. With this achievement, this student, P5, could underline 21 words and unpacked 21 words out of 22 nominalizations. In the test, P 5, only failed in identifying one nominalization television. In the interview session, he argued that the word television was known as it was but its base form was not learned. It was reported when interviewed that this ability was supported by his experience to learn English in many ways, by joining a sponsored English program in high school and by learning English through Internet and games.

This study is summarized into two cases. They were about some participants who did not do the test correctly. The first case was that they did not find nominalizations in the reading text because they did not know that those words were nominalizations, for examples, written in the test paper, ability, television, and well-being.

The second case was that they could identify the nominalizations, but they did not know the base forms or roots of those words. It was as if, for some students, the words in the forms of nominalizations were more common than their roots. In this case, because of unfamiliarity with their base forms, then they failed to unpack those nominalizations, for examples, taken from the test paper, opportunities and ability.

This second case was revealed by some interview data as follows. The students recognized that a certain word was nominalization but they did not know its root. They often took it for granted when finding a nominalized word, particularly when learning engineering texts in Polytechnic. They lacked of opportunity to learn or discuss about nominalized words. They often made mistakes when turning the nominalized word into its base form. In terms of the teaching method, there should be an explicit teaching on nominalizations to solve this problem, in which the teacher "makes clear what is to be learned to facilitate the acquisition of writing skills" (Hyland, 2004, p. 10).

This is in line with the statement that texts using a lot of nominalizations often appear to be very dense and can be difficult to read. This is because nominalization changes the way to 'package' information in a clause. (Ravelli \& Ellis, 2004; Droga \& Humphrey 2011)

It is also mentioned by Martin and Rose that nominalizations, like other grammatical metaphors, are read in two levels at once, a grammatical meaning and a discourse semantic meaning. Thus, difficulties arise when processes are nominalized so that activities are coded as if they were things (Martin \& Rose, 2007). That is why for most undergraduate level, or Polytechnic students, the application of nominalizations causes some troubles. Furthermore, Halliday (cited in Halliday \& Martin, 2005:76) argues that grammatical problem in scientific English is that scientific texts are found to be difficult to read, because they are written in 'scientific language,' and that scientific forms are difficult to understand. 


\section{CONCLUSION}

This study found that in average, Polytechnic students moderately understand the nominalizations realized in scientific texts. In other words, most students could identify (by underlining) nominalizations found in the reading text. Unfortunately, their ability of unpacking nominalizations was lower than underlining. They failed to unpack the nominalized words they had identified. This was an evidence of inconsistency in understanding nominalizations.

Therefore, it is concluded that the students' level of understanding of nominalizations is moderate. In other words, to an average extent, the students understand nominalization, but this level of ability is not sufficient for Polytechnic students to understand academic text.

Based on the above phenomena, there are some recommendations. Firstly, in relation to the teaching of technical English in Polytechnic, the teachers (of English subject in particular and non-English subject in general) should be aware of the role of nominalizations in scientific language. It is through nominalizations technical terms are construed. They should manage time to discuss the application of nominalizations in scientific texts, since some Polytechnic students still experienced some difficulties in understanding the texts, if not explained.

Secondly, it is specially addressed to the future researchers interested in studying the same topic. The next research should provide its participants an opportunity to apply many types of nominalization in their own written scientific texts, so that they will be able to practice their understanding of nominalizations.

\section{REFERENCES}

Banks, D (2005). On the historical origins of nominalized process in scientific text, English for Scientific Purposes, 24 (3), pp. 347-357.

Baratta, A.M. (2010). Nominalization development across an undergraduate academic degree program. Journal of Pragmatics, 42 (4), pp. 1017-1036.

Briones, S., Fortuny, L., \& Sastre, S. (2003). Grammatical metaphors in scientific English, A metafora gramatical no ingles cientifico. The ESPecialist, 24 (2), pp. 131-142.

Cullip, P. F. (2000). Text technology: The power-tool of grammatical metaphor. RELC Journal. 31(2), University Malaysia Sarawak.

Christie, F. \& Martin J.R. (2000). Genre and institution. Social processes in the workplace and school. New York: Continuum.

Crocker, R. A. (2009). An introduction to qualitative research. In Juanita Heigham \& Crocker R.A. (Eds.). Qualitative research in applied linguistics: A practical introduction (pp.3-24). Hampshire: Palgrave Macmillan.

Derewianka, B. (1998). A grammar companion for primary teachers. Erskinville: Star printery.

Dieter, G. E. (1991). Engineering design, A materials and processing approach. Second Edition. Singapore: McGraw Hill Book Co.

Droga, L. \& Humphrey, S. (2011). Grammar and meaning, An introduction for primary teachers. Berry, New South Wales: Target Texts.

Eggins, S. (2004). An introduction to systemic functional linguistics. Second Edition. London: Continuum.

Frankel, J.R. \& Wallen, N.E. (1996). How to design and evaluate research in education. New York, Ny: McGraw Hill Inc. 
Galve, I.G. (1998). The textual interplay of grammatical metaphor on the nominalizations occuring in written medical English. Journal of Pragmatics, 30 (3), pp. 363-385.

Gerot, L. \& Wignell, P. (1998). Making sense of text. Queensland: Antipodean Education Enterprises.

Glendinning, E. H. (1973). English in focus, English in Mechanical Engineering. Teacher's. Oxford: Oxford University Press.

Halliday, M.A.K. (1992). Spoken and Written Language. Oxford: OUP.

Halliday, M.A.K \& Martin, J.R. (2005). Writing science: literacy and discursive power. Bristol: The Falmer Press.

Heigham, J., \& Croker, R. A. (2009). Qualitative research in applied linguistics: A practical introduction. London: Palgrave Macmillan.

Holtz, M. (2009). Nominalization in scientific discourse, A corpus-based study of abstracts and research articles. Lancaster University Centre, Department of Linguistic and Literary Studies, English Linguistics, Technische Universität Darmstadt. Available at:holtz@linglit.tudarmstadt.de

Hornby. A.S. (2010). Oxford advanced learner's dictionary. Oxford: Oxford University Press.

Hyland, K. (2004). Genre and second language writing. The University of Michigan Press.

Knapp, P. \& Watkins, M. (2005). Genre, text, grammar. technologies for teaching and assessing writing. Sydney:

University of New South Wales Press Ltd.

Lincoln, Y. S., \& Guba, E. G. (1985). Naturalistic inquiry. Beverly Hills, CA: Sage.

Martin, J.R. \& Rose, D. (2007). Working with discourse. Meaning beyond the clause. Second Edition. London: Continuum.

Paltridge, B. (2006). Discourse analysis, an introduction. London: YHT Ltd.

Ravelli, L. J. (1999). Metaphor, mode and complexity: An exploration of covarying patterns. Nottingham: Department of English and Media Studies.

Ravelli, L. J. \& Ellis, R. A. (2004). Analysing academic writing, contextualised frameworks. Open Linguistics Series. London: Continuum.

Yuliana, D. (2011). An investigation of grammatical metaphor in students' writing and its effects on the texts' written characteristiccs. A Thesis of School of Post Graduate Studies, Indonesia University of Education. 


\section{$\underline{\text { Appendix 1: Test Paper (the answers are underlined) }}$}

\section{ENGLISH TEST}

\section{Read the reading text carefully. Identify by underlining the nominalized words resulted from derivation processes. Then put them into their roots!}

\section{TECHNOLOGICAL INNOVATION}

The advancement of technology has three phases:

Invention. The creative act whereby an idea is conceived.

Innovation. The process by which an invention or idea is brought into successful practice and is utilized by the economy.

Diffusion. The successive and widespread initiation of successful innovation.

Without question, innovation is the most critical and most difficult of the three phases. Many studies have shown that the ability to introduce and manage technological change is a major factor in a country's leadership in world markets and also a major factor in raising the standard of living at home.

Science-based innovation in the United States has spawned such key industries as aircraft, computers, plastics, and television. Relative to other nations, however, the importance of the United States role in innovation appears to be decreasing. If the trend continues, it will affect our own wellbeing. Likewise, the nature of innovation has changed with time.

Opportunities for the lone inventor_and entrepreneur have become relatively more limited. As one indication, independent investigators obtained 82 percent of all U.S. patents in 1901, whereas the corresponding number in 1967 was 24 percent. Nevertheless, small companies do make a major contribution to innovation in this country.

Good Luck!

The text is taken from 'Engineering Design' by George E. Dieter (1991). 